\title{
O PROCESSO EROSIVO E O MATERIAL HIDRO-TRANSPORTADO NA BACIA HIDROGRÁFICA DO RIO PINHAL, NO SUDOESTE DO PARANÁ \\ JULIO CAETANO TOMAZONI
}

\author{
DISSERTAÇÃO DE MESTRADO - Programa de Pós-Graduação em Geologia - UFPR \\ DATA DE DEFESA: 08/05/98
}

Para avaliar a quantidade de material hidro-transportado na bacia do rio Pinhal foi instalada, no seu médio curso uma estação flúvio-sedimentométrica, para monitorar o fluxo de material particulado e dissolvido e um pluviômetro. Através desta pesquisa, ficou evidenciado que o índice de degradação da bacia está relacionado com o processo de ocupação antrópica, pois as formas de uso da terra estão distorcidas ou não são protegidas por práticas adequadas de controle de erosão. Utilizando um procedimento para ponderar as formas de uso e as práticas conservacionistas para cada situação de solo e relevo da bacia, construiu-se um mapa de caracterização da capacidade. 